UDC 662.215.4

O. L. Kyrychenko, Cand. Sc. (Tech.), orcid.org/0000-0002-1331-9323
DOI: $10.29202 /$ nvngu/2018/7

State Enterprise Research-Industrial Complex "Pavlohrad Chemical Plant”, Pavlohrad, Ukraine, e-mail: alekseyphz@ gmail.com

\title{
ON THE INFLUENCE OF THE DENSITY OF LASER BEAM ENERGY ON THE SENSITIVITY OF EXPLOSIVE SUBSTANCES TO LASER RADIATION
}

Purpose. Determining the patterns of distribution of energy density over the laser beam diameter and the features of influence of beam diameter on the change in sensitivity of explosives to laser pulsed radiation.

Methods. Experimental investigations of initiation of explosion of certain initiating explosives which are lightsensitive to the action of laser radiation. Analysis and synthesis of investigation results.

Findings. The experimental investigations have been carried out and the results have been assessed. The functional independence of the size effect on the laser generation has been determined.

Originality. It has been established that the values of the threshold energy density and the critical density of the minimum threshold energy of initiation of lead azide samples in the form of pre-compressed powder and microparticles distributed in the polymer matrix depend on the diameter of the laser beam. As the diameter increases, the threshold energy density of initiation decreases sharply, while the critical density of the minimum threshold energy of initiation rises. The patterns are maintained regardless of the way the samples are made. The function of the distribution of irradiance in the volume of explosive does not depend on the laser power density. The increase in the optical strength of the diffusing medium with a decrease in the laser beam - medium interaction zone is associated with a decrease in the number of absorbing microinhomogeneities, and is accompanied by a sharp increase in the statistical dispersion of the experimental data. In this case the medium is diffusive, so the initiation occurs at a certain depth, where a dispersion halo is able to form.

Practical value. The method of laser excitation of detonation is a promising for application to various means of initiation, in particular, when blasting charges from explosive microvolumes to the simultaneous detonation of the whole explosive surface with an area of several square meters.

Keywords: energy-saturated composites, explosives, laser, radiation, energy of radiation, initiation

Introduction. The requirements for the safe and precise blasting dictate the need for creation of new initiation systems of explosive charges with greater physical and technical potential, which are safer to handle and when wiring the firing circuit. One of such systems, which differs from those known for its high resistance to any human-made electromagnetic effects, is a specimen of the experimental optical system of charge initiation OPSIN, made in 1994 by the National Mining University (Ukraine) [1]. At present, this first model of the laser system in the world is used as a basic technical system to improve the design of individual elements and units, while the experimental investigations of new light-sensitive explosive compositions are being carried out.

Investigations of initiating explosives and high explosives were extensively carried out in the 1960s-1990s of last century (A.A. Brish, I.A. Galeev, B. N.Zaytsev (1968); Y. Mizushima, I. Nishiya (1975), J. Robert (1976); E. I.Aleksandrov， A. G. Voznyuk (1978); J.T. Hagan, M. M. Chaundhri (1981); Yu. F. Karabanov, V. K. Bobolev, (1981); V. E. Aleksandrov, A. V. Dolgolaptev, V. B. Ioffe, et al. (1983); A. V. Chernai, Yu. P. Kuchugurnyi (1986); V.E.Aleksandrov, A. G. Voznyuk, V.P.Tsipilev (1989); V. N. Lobanov, R. G. Lenskiy, Yu. I. Plotnikov, et al. (1989); Yu.F. Karabanov, I.A. Karpukhin (1992), M.A. Ilushin, A. M. Sudarikov, I.V. Tselinskiy, and others. (1980-2016), A. V. Chernai, V. V. Sobolev (1994-2016), Y. Lien, et al.

(C) Kyrychenko O. L., 2018
(2010) and many others). In the present century the efforts of scientists are concentrated on the development of new light-sensitive explosives, laser initiation systems (N.A. Leonenko, 2002), optical detonators [2] and application of such systems in machine engineering, mining industry and military arts. Thus, the results of using the laser method of initiating explosive charges in metal welding, hardening and marking by explosion are presented in the work of V.A. Chernai, Yu. P. Bunchuk and S. N.Pakhomov (2003) in investigations of the evolution of fiberoptic systems as promising means for high-energy materials detonation [3], including usage of laser diodes [4].

A large number of studies have been carried out with various energy-saturated light-sensitive compositions for spacecraft pyroautomatic systems [5], for high explosives initiating devices [6] when studying the properties of energy-saturated compounds [7], and the following results were obtained:

- a number of important scientific results in the course of investigating the sensitivity of high explosives to the laser diode initiating pulse [8] and metal complexes in energetic compositions, such as di- (3-hydrazino4-amino-1,2,3-triazol) -copper (II) perchlorate [9];

- demonstration of possible application of abnormally sensitive explosives on large-area curved surfaces (more than $1 \mathrm{~m}^{2}$ ) [10];

- suggestion of a method of sub-microsecond load with a density of $0.08-1.0 \mathrm{kPa} \times \mathrm{s}$ upon spacecraft body shells [11]; 
- development of a number of technical solutions for generation of profiled shock waves [12];

- investigation of the chemical patterns to transform energy-saturated substances influenced by coherent radiation [13].

In regards to practical application, the obtained results indicate that the laser initiation provides a high level of safety, reliability and accuracy. Isolation of the optical detonator from pseudo-pulses transmitted over the communication line to the laser is due to the fact that the optical range does not cover the random sources having a sufficient power to initiate the detonator. In addition, the optical detonators are insensitive to electromagnetic pickup and static electricity charges. It was only possible to achieve a set of such positive and very important characteristics after synthesis of light-sensitive energy-saturated composites and their testing within optical detonators as primary initiating explosives [1, $5,7]$. Similar results obtained in [14] confirm the conclusions stated in earlier works.

The leading organizations that deal with the problems of laser initiation of chemical processes in energysaturated substances include universities, laboratories, institutes and enterprises, engaged mainly in military and mining industries. First of all, special mention should go to St. Petersburg Polytechnic University, Samara State Aerospace University and Technical University, Institute of Chemical Physics of Russian Academy of Sciences (Russia), Institute of Optoelectronics, Military University of Technology (Poland), Los Alamos National Laboratory, the National Aeronautics and Space Agency and a number of universities of the United States.

In Ukraine the National Mining University researches a problem of laser initiation of explosives. The main problem facing the researchers in this developing area of knowledge is the development, synthesis and use of new primary initiating explosives sensitive to the action of laser radiation. Such substances were obtained by scientists and specialists from St. Petersburg Polytechnic University in cooperation with specialists from the National Mining University (Ukraine) [6, 9, 13]. Synthesis of initiating primary light-sensitive explosives, which are characterized by abnormally high sensitivity to the action of laser radiation, initiated the development of works on creation of a new competitive system of laser initiation of explosive charges based on the laser blasting method.

To improve the work safety and the physical and technical efficiency of some modern explosive technologies, the systems for initiation of explosive charges, such as NONEL, Magnadet, and others are used. The complete satisfaction of sufficiently strict requirements of industrial technologies and the need to ensure a high level of safety depends mainly on the optical detonator - as the most important element of the initiation system [1, 14].

The optical detonator contains a light-sensitive explosive, whose power is sufficient to initiate detonation in standard secondary explosives. At present, several dozens of light-sensitive explosives [5,6] have been synthesized; however, their usage requires the computational models which allow determining the parameters of the laser action and recommending reasonable physical and geometric characteristics of light-sensitive explosive charges in optical detonators. Building of computational models requires, in general, knowledge of a laser ignition mechanism and, in particular, the patterns of irradiance in the volume of explosive. As shown in the results of studies (E.I.Aleksandrov, A. G. Voznyuk, V. P. Tsipilev, et al.), the calculation of the irradiance in the volume of explosive is complicated, since the explosive is a medium with a high density of diffusers, for which analytical solutions have not been obtained.

The above obstacles were eliminated by developing and solving a physico-mathematical model of light propagation in a diffusive-scattering medium with a high density of diffusers [15]. Solving this problem required the results of experimental studies obtained in [9-13]. The problem of light propagation in scattering media has been the subject of study by many specialists over the last decades.

At the end of the second half of the last century this branch of science was intensively developed by the Institute of Chemical Physics, the Academy of Sciences of the USSR (Moscow), and by the established Institute of Atmospheric Optics (Tomsk). The main research direction was related to problems of optical detection, air pollution in industrial regions of the country, as well as of medicine. Similar problems were also researched in the US and countries of Western Europe. The main attention was paid to solving the problem of light beam attenuation in media with a low concentration of diffusers (fog, polluted air, and others).

It is a small concentration of diffusers that made it possible to convert the nonlinear light propagation equation into a linear one. Not least important are the physical values characterizing the laser radiation, its energy characteristics, geometrical parameters of the laser beam and their interconnection to build optical detonators. These parameters generally ensure reliability and minimization of the initiation energy of light-sensitive composite explosives; determine the reasonable dimensions of special designs of optical detonators, including micro detonators.

The work objective is to establish the patterns of the distribution of the energy density over the laser beam diameter and the effects of the beam diameter on the change of the explosives' sensitivity to laser pulsed radiation.

Materials and investigation procedures. Experimental device (Fig. 1) is the one created on the basis of a solid-state optical quantum generator CFR 20010 Pulsed Nd: YAG Laser System Big Sky Laser (USA). The emission wavelength is $1.064 \mu \mathrm{m}$, vertical polarization, maximum energy per pulse is $200 \mathrm{~mJ}$. The laser operates in a repetitively-pulsed mode with frequency control ranging within $170-10 \mathrm{~Hz}$. The pump lamp flash frequency rate is constant and equals $10 \mathrm{~Hz}$. The first modulated pulse appears after generating 20 pulses. The laser operation stabilizes after ten modulated pulses. 
The diameter of the initial beam is $6 \mathrm{~mm}$, the difference at the pulse energy, amounting to $85.5 \%$ of the maximum value, is 2.8 millirad. The investigations involved photosensitive films of energy-saturated composites based on lead azide. The polymer introduction makes it possible to avoid the aggregation of submicron explosive particles, and the phlegmatization of lead azide has virtually no effect on its detonation characteristics.

Fig. 1 shows the diagram of the experimental device developed by the specialists of the National Mining University. The number 1 stands for an optical quantum generator - laser (Nd: YAG). Laser diode 2 and diaphragm 15 were used to align the optical wavelength path. By means of prism 4, the laser beam was directed to explosive 11, applied in the form of $5 \mathrm{~mm}$ diameter coating onto the glass plate 10 . A sample of the lightsensitive composite was fixed on aluminum plate 9 of $8 \mathrm{~mm}$ thickness. For laser radiation to pass, the plate had an $8 \mathrm{~mm}$ diameter hole. The lens 7 was used to adjust the required diameter of the laser beam. The central part of radiation, which was formed by a diaphragm having a cutout circular hole in the center, was used to initiate the process. The image was projected by means of a lens on the surface of a light-sensitive composite explosive. The image plane was determined with indentation produced on the film; the boundaries quality and size were evaluated with a microscope.

Photodiode 12 registered the ignition of photosensitive explosive. Light filters 5 were designed to measure the energy of laser radiation which falls on the sample, at a fixed distance from the photosensitive explosive to the lens. To determine this energy, an energy meter of pulsed laser radiation, IEL-300, was used with a measuring pass-through head 6. To measure the delay time of ignition of the photosensitive explosive relative to the beginning of laser pulse action, photodiodes 12 and 13 operating in spectral ranges of $0.4-1.2 \mu \mathrm{m}$ and $0.8-1.4 \mu \mathrm{m}$, respectively, were used. In the course of the experiments, it was found out that an explosion delay of photosensitive explosive can be registered with a single photodiode 12. A two-channel digital oscilloscope TDS-350 from Tektronix (USA) was used. The maxi- mum frequency of the input signal (analog) is $200 \mathrm{MHz}$. The maximum frequency is $1 \mathrm{GHz}$. The minimum sweep time is $2.5 \mathrm{~ns} /$ div.

To determine the energy density distribution function in the laser beam, we used a technique based on the experimental determination of the diameters of prints that occur when radiation acts upon the surface of the material. Energy distribution in the laser beam was determined using a Silicon Camera Model LBA-100A laser beam analyzer (from Spiricon). The analyzer includes high resolution cameras Pulnix TM-745, which directly register radiation, and microprocessor systems that analyze the energy distribution and display the results on the monitor.

Due to the fact that when the energy in the laser pulse changes, the diameter of the irradiation spot also changes (the absolute value of the energy density at the beam boundary remains unchanged), A. Chernai proposed a technique for measuring the diameter of a laser spot using imprints on developed photographic paper exposed to light. In the substance laid off on the surface of the photographic paper, phase transformations occur which can be observed visually or with the help of a microscope. The phase transition has a threshold nature, that is, it is realized under the action of laser radiation with the energy whose density exceeds a certain threshold value $E^{*}$. In this case, contrasting prints are obtained on the surface of the material, which can be measured with sufficiently high accuracy.

Pursuance of research and discussion. In the research methods, a requirement for research conditions is formulated, in accordance with which the function of distribution of radiation intensity along the diameter of the laser beam should not vary from pulse to pulse. This requirement is fulfilled under stable operation of an optical quantum generator (OQG), which generates pulses having the same energy. When necessary, radiation energy density was changed using calibration light filters.

In determining sensitivity thresholds of explosives, the central part of the laser beam was separated with a diaphragm of a $4 \mathrm{~mm}$ diameter, which corresponded to a level of intensity being half of its maximum value. Later such beams were studied in terms of their quality.

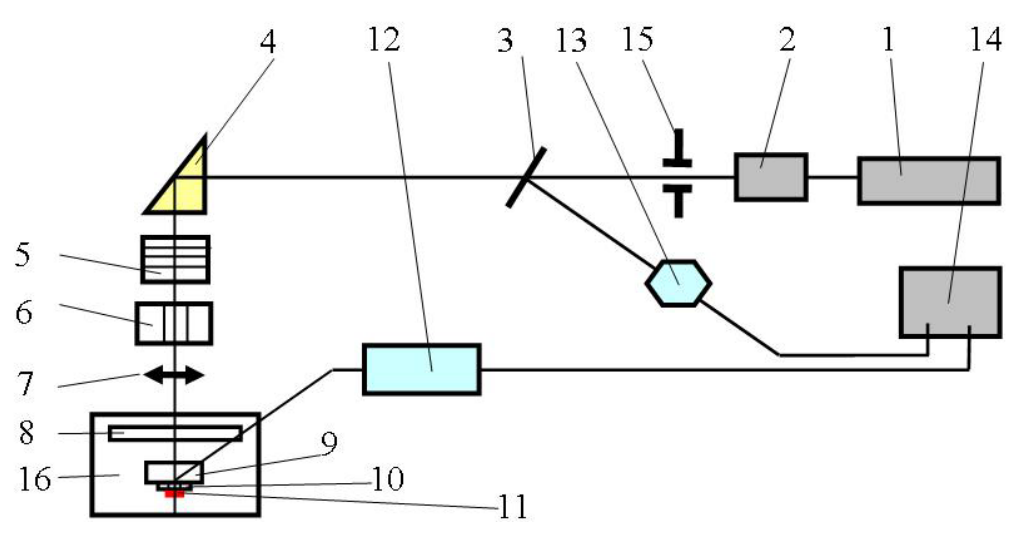

$a$

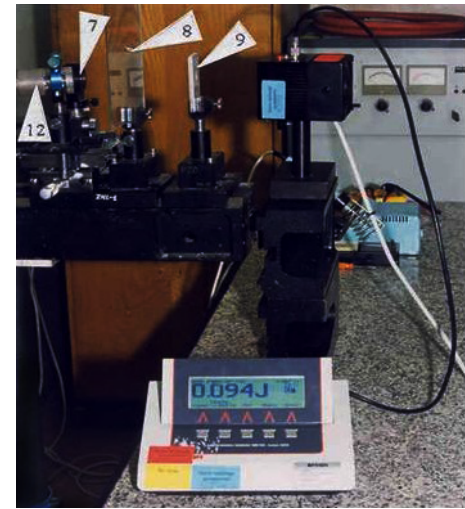

b

Fig. 1. Experimental device:

$a$-schematic circuit diagram; $b$ - general view of stationary optical quantum generator 

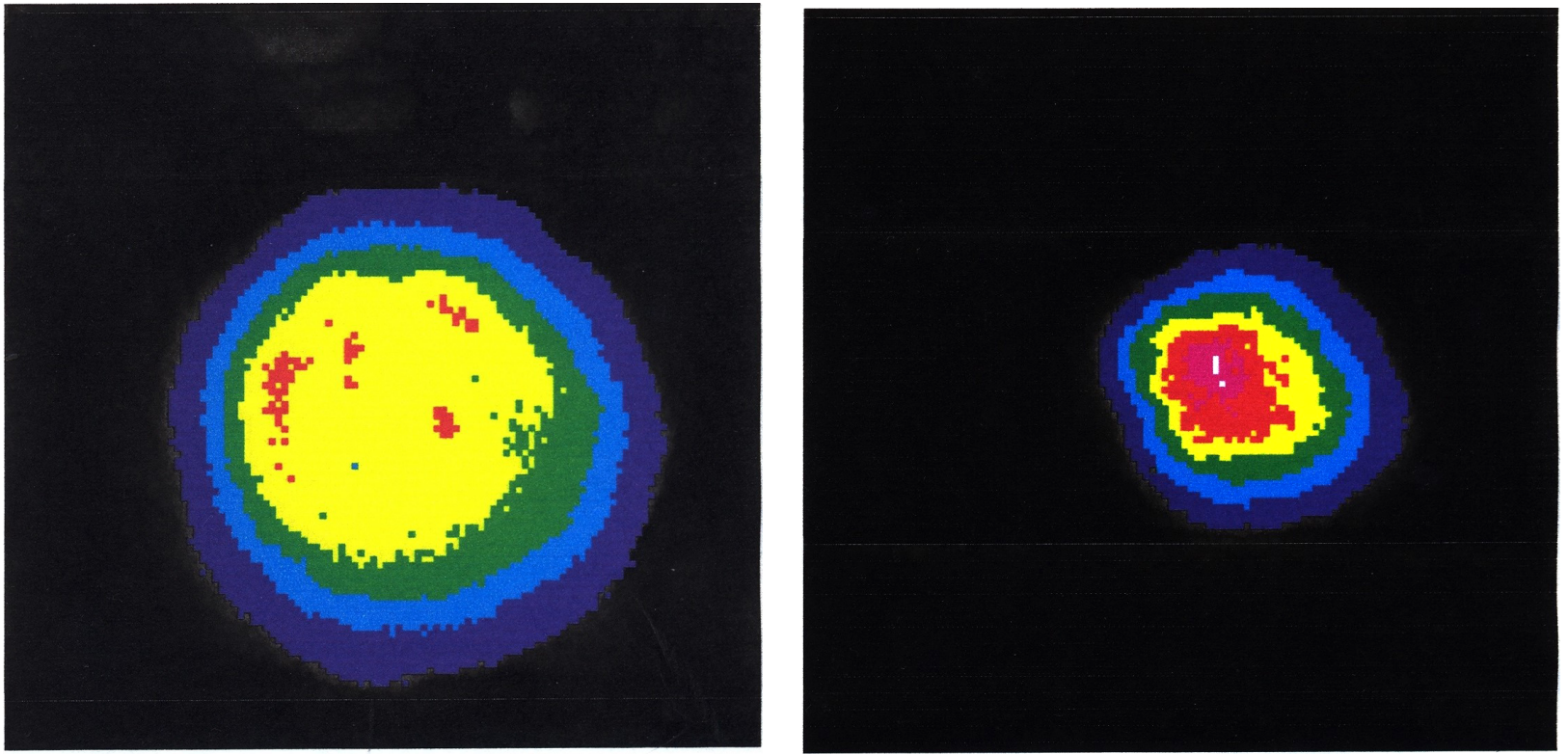

Horizontal Cursor Profile

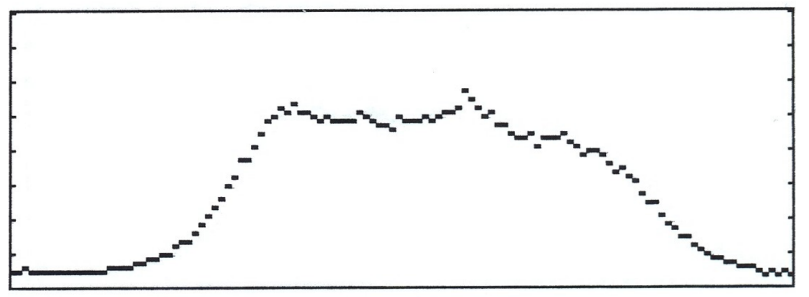

Horizontal Cursor Profile

Vertical Cursor Profile
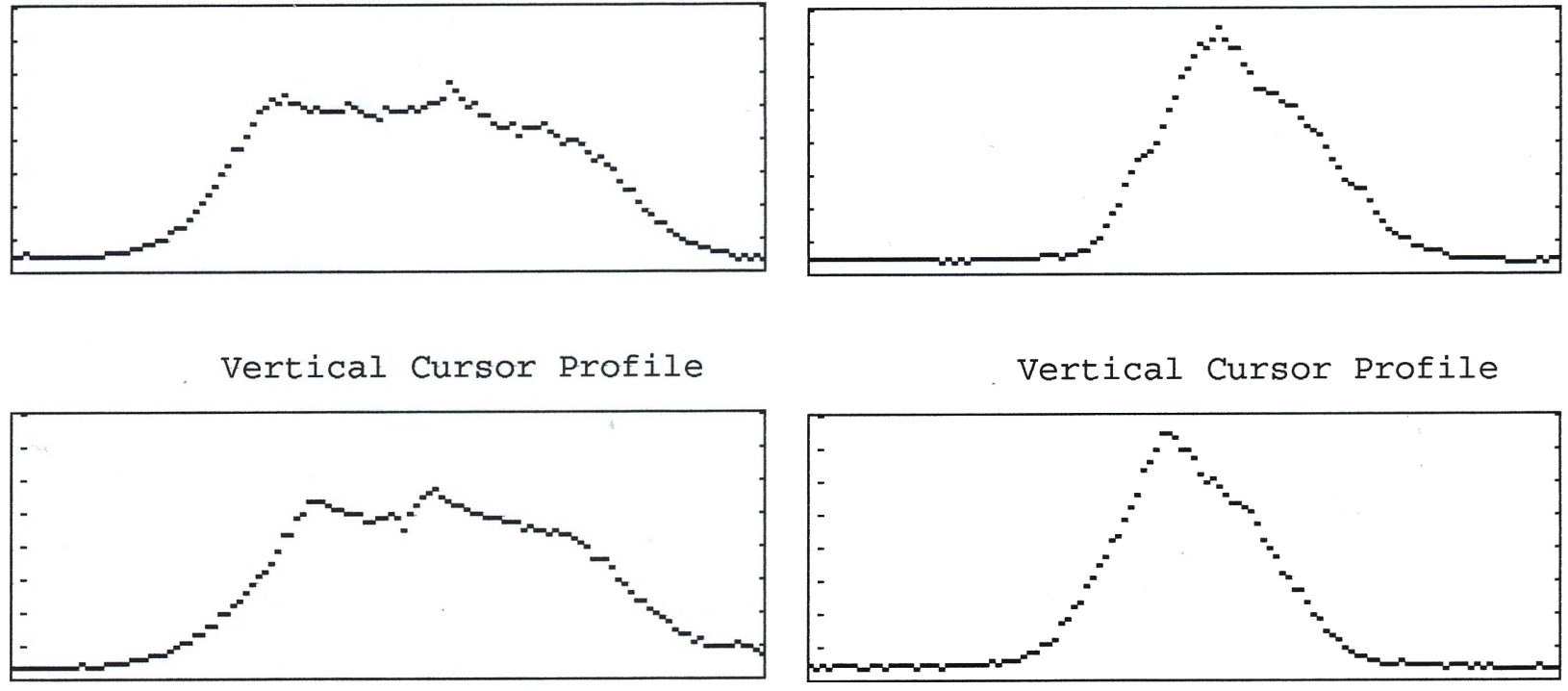

$a$

Vertical Cursor Profile

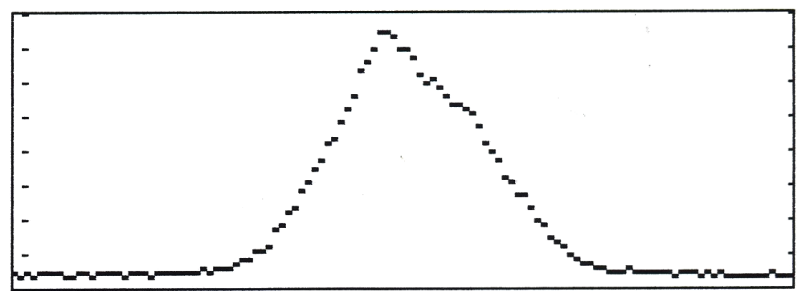

$b$

Fig. 2. Energy density distribution of laser radiation in an irradiation spot:

$a$-diameter of laser print of $5 \mathrm{~mm} ; b$-diameter of laser print of $2.75 \mathrm{~mm}$

Fig. 2 shows a typical distribution of intensity along vertical and horizontal beam cross-sections, obtained with the Silicon Camera Model LBA-100A analyzer. The uneven distribution of the intensity of illumination did not exceed $30 \%$.

We will approximate energy density distribution in terms of beam section as

$$
E(r)=E_{0} \omega(r),
$$

where $E_{0}$ is an energy density at the centre of the beam; $r$ is the radius of the ring with a width of $d r$, on which the value $E(r)$ is searched.

Representation of energy density function in the form (1) provides for the radial symmetry of the distribution function. We normalize this function to total energy in pulse $W$

$$
W=2 \pi E_{0} \int_{0}^{\infty} \omega(r) r d r .
$$

Dividing (1) by (2), we obtain

$$
E(r) / W=\omega(r) / 2 \pi k,
$$

where $k=\int_{0}^{\infty} \omega(r) r d r$.

By changing the transmission of the laser path, a series of imprints, the diameters $(d)$ of which can be measured with a microscope, should be expected. The threshold of imprints corresponds to the threshold energy of $E^{*}$ color change. Fig. 3 shows an appearance of laser radiation imprints on photographic paper with measured diameters. 
Imprints in Fig. 3, $a$ were obtained by direct effect of the initial laser beam. In all the experiments diaphragms were used, by means of which the laser beam was "cut off" in such a way that only a central part of radiation passed through the diaphragm opening.

The results of imprint measurements are used to write equations as follows

$$
E^{*}(r) / W_{i}=\omega\left(r_{i}\right) / 2 \pi k, \quad i=1, \ldots, n,
$$

where $n$ is a quantity of measurements; $W_{i}$ is a radiation energy, at which radius of an imprint is $r_{i}$.

After plotting $W(r)$ dependence by extrapolation method, the energy of $W(0)=2 m J$, at which radius of an imprint is zero was found.

Then, the threshold energy of the phase transformation of the coating material on photographic paper was determined

$$
E^{*} / W(0)=\omega(0) / 2 \pi k=1 / 2 \pi k .
$$

Diving equation (3) by (4), we obtain

$$
\omega\left(r_{i}\right)=W(0) / W_{i}, \quad i=1, \ldots, n .
$$

Knowing a distribution function $\omega(\mathrm{r})$ is completely sufficient to solve the problem. To determine the energy density at the center of the beam $E_{0}$, as well as $E^{*}$ by graphical integration, the value $k=4.96 \cdot 10^{-3} \mathrm{~cm}^{2}$ was found.

The energy density at the center of the beam $E_{0}$ is calculated by the formula

$$
E_{0}=W /(2 \pi k) .
$$

As the sensitivity characteristic, the average energy density of the laser pulse

$$
E_{a v}=4 \mathrm{~W} / \pi d^{2},
$$

or the energy density at the center of the beam $E_{0}$ was chosen.

A comparatively small number of research studies are known to be related to the study of dependence of critical (threshold) initiation energy density $E_{c r}$ on the diameter of the laser beam $\mathrm{d}$, that is, on the size of the irradiated area (with allowance for size effect). The size effect was first detected for lead azide (A.A. Brish, I. A. Galeev, B. N. Zaitsev).

The value $E_{k}$ is practically independent of the beam diameter if $d>d_{0}$, where $d_{0}$ is the value of the diameter

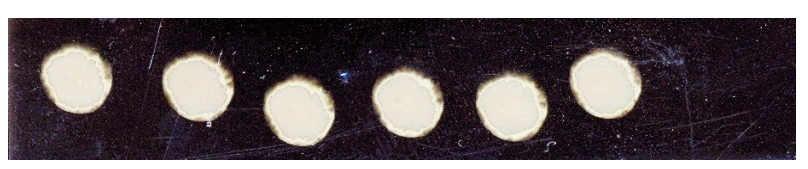

$a$

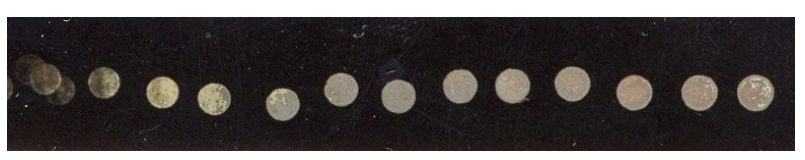

$b$

Fig. 3. Laser beam imprints on the surface of photographic paper active layer:

$a-6 \mathrm{~mm}$ diameter imprint; $b-$ mean diameter of $2.7 \mathrm{~mm}$ at which the character of the dependence changes. For lead azide $d_{0} \cong 0.1 \mathrm{~mm}$, for a secondary explosive PETN with a dispersion of $5500 \mathrm{~cm}^{2} / \mathrm{g}-$ it is about $0.6 \mathrm{~mm}$ and decreases with increasing dispersion. The critical density of initiation energy (for wide beams) when lead azide is blasted is close to $0.4 \mathrm{~J} / \mathrm{cm}^{2}$, for PETN it is $\approx 53 \mathrm{~J} / \mathrm{cm}^{2}$. This dependence of the critical energy density on the beam diameter is practically preserved when changing over from a wavelength of $1.06 \mu \mathrm{m}$ (neodymium laser) to $0.63 \mu \mathrm{m}$ (ruby laser), which agrees with the results of measuring the reflection coefficient of explosives at these wavelengths, which turned out to be approximately equal to $80 \%$ for lead azide and PETN.

Aleksandrov V. E., et al., (1983) showed that the existence of a dimensional effect does not allow comparing the available data for various condensed explosives due to the fact that studies were carried out at different laser beam diameters. A correct comparison of the results can be made in the case of generalized dependence

$$
E_{c r} / E_{c r}^{0}=1+\left(d / d_{c r}\right)^{-3}
$$

$E_{c r}^{0}$ is a minimum (asymptotic) value of the critical energy density corresponding to $d \rightarrow \infty, d_{c r}$ is a critical detonation diameter characterizing the ability of an explosive to perform a high-speed chemical transformation.

The dimensional effect was the most completely investigated in [9] using lead azide samples obtained in the form of pellets under a pressure of $2 \cdot 10^{9} \mathrm{~Pa}$. The reflection coefficient of the samples of explosive is equal to $\mathrm{R} \cong 88 \%$. Figs. 4 and 5 show the results of measurements of dependence of initiation energy threshold den-

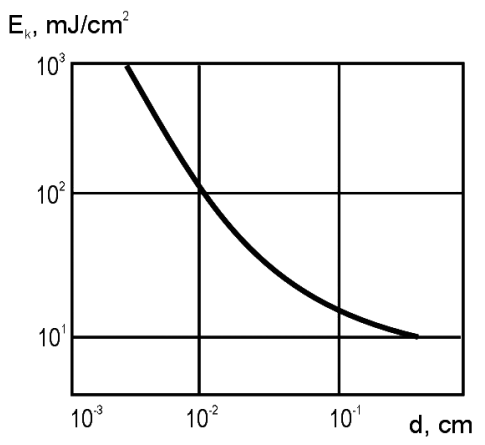

Fig. 4. Dependence of initiation energy threshold density $E_{k}$ on laser beam diameter $d[9]$

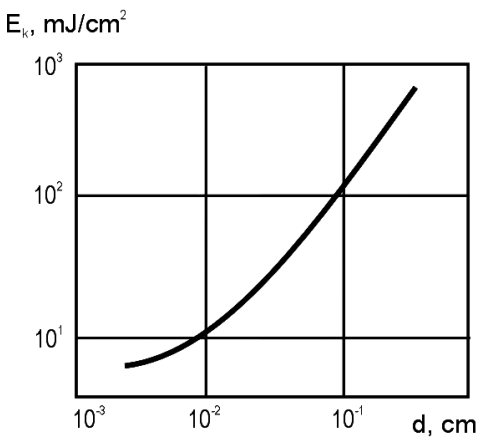

Fig. 5. Dependence of initiation energy critical density $W_{k}$ on laser beam diameter $d$ [9] 
sity $E_{k}$ and critical initiation energy $W_{k}$ on the laser beam diameter.

Similar studies were carried out on lead azide samples in a polymer matrix, which had the average reflection coefficient of $82 \%$.

Figs. 6 and 7 show the results of measurements of dependence of initiation energy threshold density $E_{k}$ and critical initiation energy $W_{k}$ of a composite material consisting of a polymer matrix filled with lead azide microparticles.

A single-mode, single-frequency optical quantum generator on neodymium glass, consisting of a generator, that generates pulses, and two identical amplifying stages, was used in the experiments. This is dictated by the fact that multimode generators due to the presence of a complex spatial structure of the light beam, do not allow the correct solution of the problem posed. The total radiation energy of the optical quantum generator was $0.51 \mathrm{~J}$.

Lead azide initiation energy critical density decreases with decreasing the beam diameter. Starting from a diameter of $4 \cdot 10^{-3} \mathrm{~cm}$, a flattening of this curve is observed, i.e. energy tends to some minimum. With a beam diameter of $2 \cdot 10^{-3} \mathrm{~cm}$, the initiation energy density is $6 \mathrm{~mJ} / \mathrm{cm}^{2}$.

Under the influence of a laser monopulse on a highenergy lead azide-based composite substance, the dependences of the energy threshold density $E_{k}$ and the critical initiation energy $W_{k}$ differ markedly from those presented in Fig. 7. In general, the nature of dependenc-

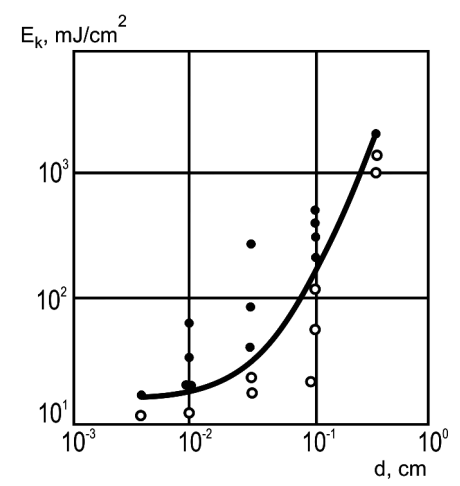

Fig. 6. Dependence of initiation energy threshold density $E_{k}$ on laser beam diameterd

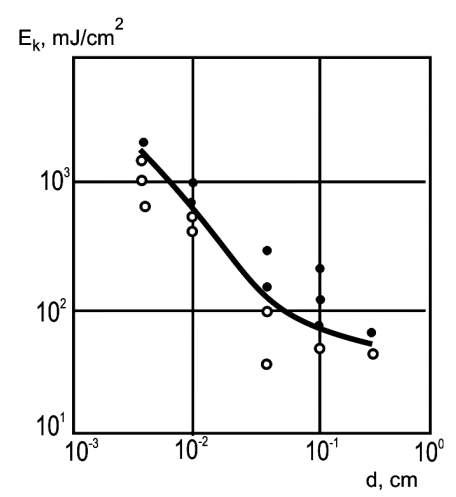

Fig. 7. Dependence of minimum threshold initiation energy critical density $W_{k}$ on laser beam diameter d es is repeated. The minimum value $W_{k}$ is $\sim 18 \mathrm{~mJ} / \mathrm{cm}^{2}$ at a laser beam diameter of $6 \cdot 10^{-3} \mathrm{~cm}$. When the beam diameter is $0.5 \mathrm{~cm}$, the initiation energy threshold density is $\sim 80 \mathrm{~mJ} / \mathrm{cm}^{2}$. Similar results were obtained when laser radiation was applied to a photosensitive composite VS-2 (Table) [6].

As the beam diameter decreases, lead azide critical initiation energy decreases, and as a whole, $W_{k} \rightarrow W_{\text {min }}$ at $d \rightarrow 0$. The statistical spread of the values $E_{k}$ and $W_{k}$ does not depend on the irradiator area, which confirms the trend observed in publication [9]. This circumstance identifies this specific feature of lead azide initiation. The increase in the optical strength of media with decreasing dimensions of the laser beam (interaction zone) is associated with decrease in the number of absorbing microinhomogeneities, accompanied by a sharp increase in the statistical spread of the experimental data. In the given case, the medium is diffusely scattering, so the initiation occurs at a certain depth, where a halo of scattering succeeds in forming.

Analyzing the results of the experiments, we determined that the required energy density in the singlepulse lasing mode, which is necessary for excitation of detonation in explosive charges, is 6-10 times lower than in the free-running lasing mode.

For practical application of laser initiation (the case of design of laser means of initiation), an important regularity is the dependence of increasing the ignition delay time when the energy of the laser beam is reduced [5, 9], Fig. 8. When determining the explosion delay time with respect to laser pulse radiation, one photodiode was used (position 12 in Fig. 1). On the oscillograms, the first peak on the left corresponds to the laser pulse radiation. The second peak (on the right) occurs when the photodiode is discharged as a result of the maximum light emission from explosion products.

To determine the ignition mechanism of explosives, it is necessary to take into account the following important results:

1) the light scattering in materials with a high density of scatterers occurs mainly on surfaces of different microinhomogeneities;

2) in synthesizing explosives, one should not attempt to use pure source materials, since the concentration of microinhomogeneities decreases, and, consequently, the probability of initiation by a laser pulse with a given energy is reduced.

\section{Table}

Influence of laser radiation coverage zone dimension on sensitivity of mercury salt of 5-hydrazinotetrazole in polymer inert matrix (BC-2) [6]

\begin{tabular}{|c|c|c|}
\hline $\begin{array}{c}\text { Laser beam } \\
\text { diameter }(d), \\
\mathrm{mm}\end{array}$ & $\begin{array}{c}\text { Critical initiation } \\
\text { energy } E_{k}, \mathrm{~mJ}\end{array}$ & $\begin{array}{c}\text { Critical initiation } \\
\text { energy density } W_{k}, \\
\mathrm{~mJ} / \mathrm{cm}^{2}\end{array}$ \\
\hline 0.48 & 0.018 & 10.46 \\
\hline 3.25 & 0.600 & 7.52 \\
\hline 9.50 & 1.900 & 2.77 \\
\hline
\end{tabular}




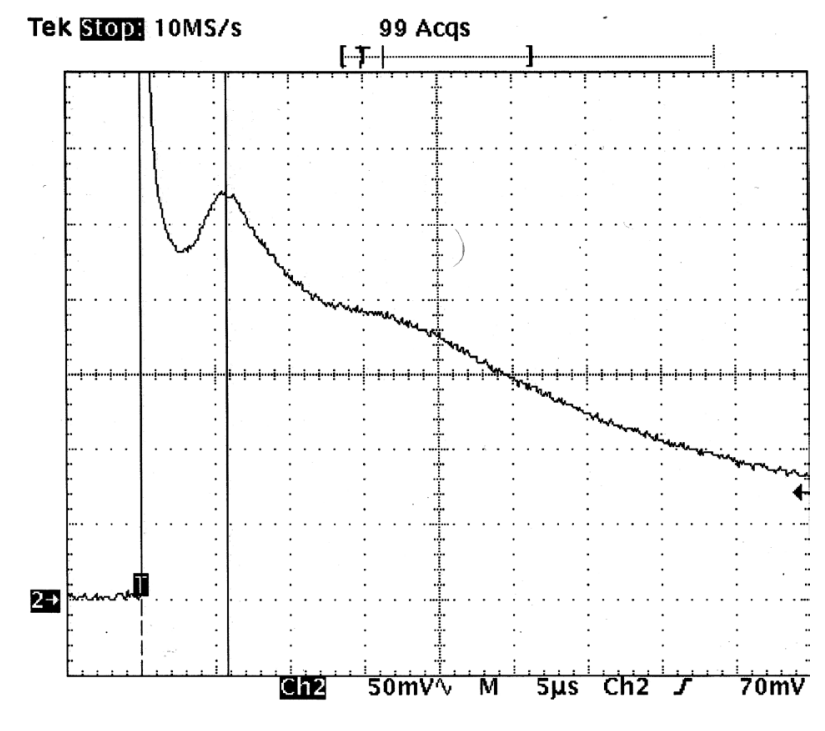

$a$

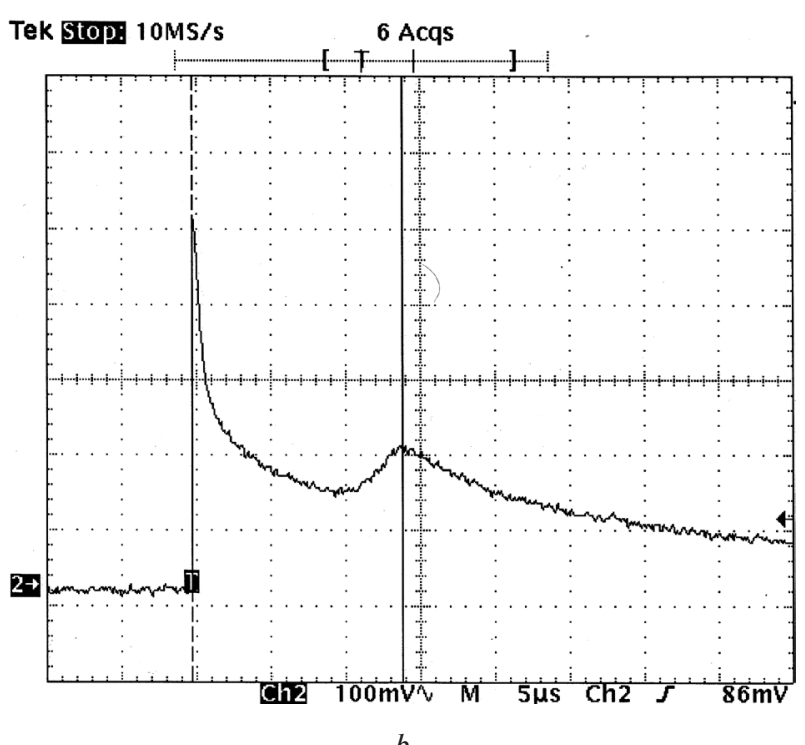

$b$

Fig. 8. Oscillograms of recording the explosion delay time for samples of explosives:

$a$-Sample 1 (thickness is $1.6 \mathrm{~mm}$, binder content is $5 \%$, laser beam energy is $E=85.57 \mathrm{~mJ}$, delay time is $0.38 \mu \mathrm{s}$ ); $b-$ Sample 2 (thickness is $2.5 \mathrm{~mm}$, binder content is $10 \%$, laser beam energy is $E=49.7 \mathrm{~mJ}$, delay time is $1.35 \mu \mathrm{s}$ )

Conclusion. An increase in the optical strength of media with a decrease in the laser beam dimensions (interaction zone) is associated with a decrease in the number of absorbing microinhomogeneities of "dangerous" value, accompanied by a sharp increase in the statistical spread of the experimental data. In this case, the medium is diffusely scattering, so the initiation occurs at a certain depth, where a halo of scattering succeeds in forming.

The energy density and the energy of initiation of lead azide by a laser pulse train significantly exceed the corresponding values for a single-pulse action.

The irradiance distribution function in the volume of an explosive does not depend on laser radiation power density.

It is shown that the laser initiation of energy photosensitive materials is a safer method of exciting detonation than the known non-electric ones. This circumstance is associated initially with the fact that composite high-energy substances are phlegmatized primary and secondary initiating explosives and are characterized by an abnormally high sensitivity to laser pulse radiation. The method is promising for use in various means of laser systems initiating; blasting of charges of microscopic masses and volumes is possible. Low values of sensitivity of composite explosives to laser pulse make it possible to start detonation of a layer of an explosive simultaneously on its entire surface, irrespective of the configuration.

\section{References.}

1. Sobolev, V., Chernai, A. and Studinsky, N., 1996. OPSIN - a new system of blast-hole change blasting in explosives. In: Procedings of the Fifth International Simposium on Mine Planning and Equipment Selection. Rotterdam: AA Brakeman Publishers [online], pp. 441-443. Available at: <https://www.bookdepository.com/Mine-
Planning-and-Equipment-Selection-96-Proceedingsof-the-Fifth-International-Symposium-Sao-PauloBrazil-22-24-October-1996-WT-Hennies-Etc-LAyres-de-Silv-P-Chaves/9789054108276? ref=bd_ recs_1_1> [Accessed 11 September 2017].

2. Kuratov, S., Serezhkin, A. and Chesnokov, A., 2015. Physico-Mathematical Model of Laser Detonator. Physical-Chemical Kinetics in Gas Dynamics, 16(1), pp. 1-9. 3. Sazonnikova, N.A., 2013. Laser initiation of detonation of high-energy substances. Saarbrücken: LAP LAMBERT Academic Publishing GmbH\&CO.KG.

4. Hand, C. F., 2010. Novel 300-watt single-emitter laser diodes for laser initiation applications. Proc. SPIE 7795, Optical Technologies for Arming, Safing, Fuzing and Firing VI [e-journal], Volume 7795, 779507. DOI: $10.1117 / 12.861447$.

5. Iliushin, M.A., Kotomin, A. A., Dushenok, S.A. and Yefanov, E. F., 2017. Laser initiation a photosensitive energy materials, that are promising for systems pyroautomatic spacecrafts. Vestnik NPO imeni S. A. Lavochkina [pdf], 1(35), pp. 43-52. Available at: <http://www.laspace.ru/upload/iblock/c1d/c1d4330a58a437cdce27cd471b97975c.pdf> [Accessed 24 January 2018].

6. Iliushin, M.A., Tselinskii, I. V. and Kotomin, A. A., 2013. High power substances for arsenal of initiation. St. Petersburg: SPbGTI(TU).

7. Iliushin, M.A., Smirnov, A. V., Sudarikov, A. M. and Tselinskii, I. V., 2010. Metallic complexes in high-energy materials, St. Petersburg: LGU im. A. S. Pushkina [online]. Available at: <https://search.rsl.ru/ru/record/ 01004801337> [Accessed 3 November 2017].

8. Fang, X. and Ahmad, S. R., 2016. Laser Ignition of an Optically Sensitised Secondary Explosive by a Diode Laser. Central European Journal of Energetic Materials, 13(1), pp. 103-115.

9. Chernai, A. V., Sobolev, V.V., Chernai, V.A., Iliushin, M.A. and Dlugashek, A., 2003. Laser initiation of 
charges on the basis of di-(3-hydrazino-4-amino-1,2,3triazol)-copper (II) perchlorate. Fizika Goreniya i Vzry$v a$ [pdf], 39(3), pp. 105-110. Available at: <http://www. sibran.ru/upload/iblock/c21/c21 a e fbffd79e0c9dbcdd538dc9d9fd.pdf> [Accessed 11 September 2017].

10. Chernai, A. V., Sobolev, V.V., Iliushin, M.A. and Zhitnik, N.E. 1994. Generating mechanical pulses by the laser blasting of explosive coating. Combustion, Explosion, and Shock Waves, 30(2), pp. 239-242. DOI: 10.1007/BF00786134.

11. Chernai, A.V., Sobolev, V.V., Iliushin, M.A. and Zhitnik, N. E., 1994. The method of obtaining mechanical loading pulses based on a laser initiation of explosion of explosive coatings. Fizika Goreniya i Vzryva [pdf], 30(2), pp. 106-111. Available at: <http://www.sibran. ru/upload/iblock/789/789051705b1d5f2d37dbb20809f 27ca8.pdf> [Accessed 4 October 2017].

12. Chernai, A. V. and Sobolev, V. V., 1995. Laser method of profiled detonation wave generation for explosion treatment of materials. Fizika i Khimiya Obrabotki Materialov [online], 5, pp. 120-123. Available at: <https:// www.researchgate.net/publication/287674128_Laser_ method_of_profiled_detonation_wave_generation_for_explosion_treatment_of_materials $>$ [Accessed $1 \overline{7}$ September 2017].

13. Tverianovich, A., Averyanov, A., Iliushin, M., Tverianovich, Yu. and Smirnov, A., 2015. Effect of laser radiation on perchlorate (1,5-diaminotetrazole-n2) pentaamminecobalt (III). Universum: Chemistry and Biology [online], 12(19), pp. 1-15. Available at: <http:// 7universum.com/ru/nature/archive/item/2806> [Accessed 9 September 2017].

14. Kennedy, J. E. and Chapter, I. I., 2010. Spark and Laser Ignition. in Shock Wave Science and Technology Reference Library. Vol. 5: Non-Shock Initiation of Explosives. Asay B. W. ed. Berlin, Heidelberg: Springer-Verlag [online], pp. 583-605. Available at: <https://www. springer.com/gp/book/9783540879527> [Accessed 20 October 2017].

15. Sobolev, V.V., Shyman, L. N., Nalisko, N. N. and Kirichenko, A.1., 2017. Computational modeling in research of ignition mechanism of explosives by laser radiation. Naukovyi Visnyk Natsionalnoho Hirnychoho Universytetu, 6, pp. 53-60.

\section{Про вплив щільності енергії лазерного пучка на чутливість вибухових речовин до лазерного випромінювання}

\section{О. Л. Кириченко}

Державне підприємство „НВО „Павлоградський хімічний завод“, м. Павлоград, Україна, e-mail: alekseyphz@ gmail.com

Мета. Встановити закономірності розподілу щільності енергії за діаметром лазерного пучка та особливості впливу діаметра пучка на зміну чутливості вибухових речовин (ВР) до лазерного імпульсного випромінювання.
Методика. Експериментальні дослідження збудження вибуху деяких світлочутливих вибухових речовин, що ініціюють, до дії лазерного випромінювання. Аналіз і узагальнення результатів досліджень.

Результати. Виконані експериментальні дослідження та проаналізовані отримані результати. Встановлена функціональна незалежність розмірного ефекту від режиму генерації лазерного випромінювання

Наукова новизна. Встановлено, що величини порогової щільності енергії та критичної щільності мінімальної порогової енергії ініціювання зразків азиду свинцю у вигляді спресованого порошку й мікрочастинок порошку, розподілених у полімерній матриці, залежать від діаметра лазерного пучка. Зі збільшенням діаметра гранична щільність енергії ініціювання різко зменшується, а критична щільність мінімальної порогової енергії ініціювання зростає. Закономірності зберігаються незалежно від способу виготовлення зразків. Функція розподілу освітленості в обсязі вибухової речовини не залежить від щільності потужності лазерного випромінювання. Підвищення оптичної міцності дифузно-розсіюючого середовища при зменшенні розмірів зони взаємодії лазерного пучка із середовищем пов'язано зі зменшенням числа поглинаючих мікронеоднорідностей і супроводжується різким збільшенням статистичного діапазону експериментальних даних. У даному випадку середовище є дифузно-розсіюючим, тому ініціювання відбувається на деякій глибині, де встигає сформуватися ореол розсіювання.

Практична значимість. Спосіб лазерного збудження детонації перспективний для застосування в різних засобах ініціювання і, зокрема, при підриванні зарядів від мікрооб'ємів ВР до порушення детонації одночасно всієї поверхні вибухової речовини площею кілька квадратних метрів.

Ключові слова: енергонасичені композити, вибухові речовини, лазер, випромінювання, енергія випромінювання, ініціювання

\section{О влиянии плотности энергии лазерного пучка на чувствительность взрывчатых веществ к лазерному излучению}

\section{А. Л. Кириченко}

Государственное предприятие „НПО „Павлоградский химический завод“, г. Павлоград, Украина, e-mail: alekseyphz@gmail.com

Цель. Установить закономерности распределения плотности энергии по диаметру лазерного пучка и особенности влияния диаметра пучка на изменение чувствительности взрывчатых веществ (ВВ) к лазерному импульсному излучению.

Методика. Экспериментальные исследования возбуждения взрыва некоторых светочувствительных инициирующих взрывчатых веществ к дей- 
ствию лазерного излучения. Анализ и обобщение результатов исследований.

Результаты. Выполнены экспериментальные исследования и проанализированы полученные результаты. Установлена функциональная независимость размерного эффекта от режима генерации лазерного излучения

Научная новизна. Установлено, что величины пороговой плотности энергии и критической плотности минимальной пороговой энергии инициирования образцов азида свинца в виде спрессованного порошка и микрочастиц порошка, распределенных в полимерной матрице, зависят от диаметра лазерного пучка. С увеличением диаметра пороговая плотность энергии инициирования резко уменьшается, а критическая плотность минимальной пороговой энергии инициирования растет. Закономерности сохраняются независимо от способа изготовления образцов. Функция распределения освещенности в объеме взрывчатого вещества не зависит от плотности мощности лазерного излучения. Повышение оптической прочности диффуз- но-рассеивающей среды при уменьшении размеров зоны взаимодействия лазерного пучка со средой связано с уменьшением числа поглощающих микронеоднородностей и сопровождается резким увеличением статистического разброса экспериментальных данных. В данном случае среда является диффузно-рассеивающей, поэтому инициирование происходит на некоторой глубине, где успевает сформироваться ореол рассеяния.

Практическая значимость Способ лазерного возбуждения детонации перспективен для применения в различных средствах инициирования и, в частности, при взрывании зарядов от микрообъемов ВВ до возбуждения детонации одновременно всей поверхности взрывчатого вещества площадью несколько квадратных метров.

Ключевые слова: энергонасыщенные композиты, взрывчатые вещества, лазер, излучение, энергия излучения, инициирование

Рекомендовано до публікації докт. техн. наук В. П. Курінним. Дата надходження рукопису 14.11.17. 